\title{
Effects of canopy density on spray deposition in kiwifruit
}

\author{
R.E. Gaskin ${ }^{1}$, D.W. Manktelow ${ }^{2}$, S. Cook ${ }^{3}$, W.A. May ${ }^{4}$ and R.M. van Leeuwen ${ }^{1}$ \\ ${ }^{1}$ Plant Protection Chemistry NZ, PO Box 6282, Rotorua 3043, New Zealand \\ ${ }^{2}$ Manktelow and Associates Ltd, PO Box 3415, Napier 4142, New Zealand \\ ${ }^{3}$ Kiwifruit Vine Health, PO Box 4246, Mount Manganui 3149, New Zealand \\ ${ }^{4}$ Spray-tec, 52 Williams Rd Sth, RD3, Tauranga 3173, New Zealand \\ Corresponding author: Robyn.Gaskin@ppcnz.co.nz
}

\begin{abstract}
A study was undertaken to evaluate the effects of canopy density on efficiency of spray deposition on kiwifruit pergola canopies. A dense canopy was pruned to also provide medium and lighter density canopies. Airblast sprays (water + fluorescent dye) were applied in typical dilute application volumes to the three canopies. Deposits were measured at four height positions through the canopy in both the centre-of-row and leader zones. Mean deposits on the dense canopy (at 2000 litres/ha) were inadequate and lowest in all zones; approximately 40\% less than the medium (1500 litres/ha) and light (1000 litres/ha) canopies. This suggests dense pergola canopies cannot be adequately covered by protectant sprays applied in the typical dilute volumes used by the kiwifruit industry, even with good sprayer setup. Spray deposits on all foliage zones in the medium and light canopies were generally acceptable confirming that pergola canopies can be fully protected with groundapplied sprays if they are managed to reduce their density.
\end{abstract}

Keywords pergola, airblast sprays, protectant sprays, kiwifruit management.

\section{INTRODUCTION}

Recent research studies to improve the performance of spray applications on kiwifruit have demonstrated that canopy density affects potential spray deposits and coverage (Manktelow et al. 2012). Canopy density was identified to be a more influential factor than sprayer type and setup (nozzling, calibration, application volume, etc.) in determining the efficiency of spray applications applied to a range of 'Hayward' and 'Hort16A' canopies. In New Zealand pergola kiwifruit canopies, many growers apply dilute sprays, spraying to the point of runoff with chemicals mixed at the label application rate per 100 litres of spray mixture. This is applied to foliage and fruit using application volumes of
1,000-2,500 litres/ha, increasing as the canopy develops through the season. An alternative strategy used by some growers is to apply a constant 2,000 litres/ha application volume throughout the season, regardless of canopy density.

Application of protectant sprays, mainly copper compounds, to vines is considered an essential part of providing protection against Pseudomonas syringae pv. actinidiae (Psa) infection (Max \& Max 2013). To minimise potential phytotoxicity and chemical residues from frequently applied protectant sprays, applications need to be evenly distributed through the target canopy, with deposit levels in 
all canopy zones achieving a biologically effective dose. This is especially important with protectant copper sprays, which are typically applied at a fraction of traditional copper application rates in order to minimise potential phytotoxicity.

It is possible that management to reduce canopy density is necessary to fully protect kiwifruit vines from Psa. The study reported here was undertaken to evaluate the effect of canopy density on efficiency of spray deposition and coverage on foliage in a mature pergola canopy, and to assess the implications of this for chemical application rate requirements.

\section{MATERIALS AND METHODS}

The deposit studies were undertaken in March 2012, on a commercial pergola orchard near Paengaroa, Bay of Plenty, consisting of pre-harvest Hort16A vines planted on $3.3 \mathrm{~m}$ row spacing with alternate row strip males. Three canopy densities were evaluated in the study. The existing 'dense' canopy was used, while the 'medium' and 'light' densities were achieved by strategically pruning vines to provide potential cane and leaf densities for managed canopies (M. Muller, Zespri consultant, personal communication). In the two managed canopies, all canes were removed from male leaders. Standard canopy parameters were measured for each treatment (Table 1). To determine percentage canopy gaps, photos taken directly beneath three random sites in each canopy zone in each treatment bay were image processed to calculate the percentage of planar area constituting visible sky.

Sprays were applied to the 'light' density canopy at 1000 litres/ha and to the 'medium' density canopy at 1500 litres/ha. These were considered true "dilute to runoff" spray volumes where the canopy closest to the sprayer was wetted to the point of visible drip and more distant canopy was still seen to be well wetted with spray. Sprays were applied to the 'dense' canopy at 2000 litres/ ha. Previous experience has shown that dense pergola canopies showing no light transmission (casting a block shadow with no sun flecks) at midday require at least 3000 litres/ha as a true dilute spray. However, the lower volume was used for this treatment as it reflected what has been typical industry application practice on this density of canopy. No pesticide was included in sprays, but all contained the non-hazardous fluorescent dye, Pyranin 120\% (ca 10 g/ha; Lanxess Ltd, ex Bayer NZ), as a tracer to measure deposits, and also the adjuvant Latron ${ }^{\circledR}$ B-1956 (25 ml/100 litres; Dow Agrosciences). Watersensitive papers (WSP) were used to monitor spray application on all zones in all treatments.

All sprays were applied with light winds blowing consistently across rows, in temperatures of $22-26^{\circ} \mathrm{C}$. The sprayer was a trailed Fantini Eco 2000 sprayer with an Arivac front entry $920 \mathrm{~mm}$ diameter fan and two spray rings consisting of eight nozzles per side. All spray volumes were achieved using five Albuz Article 58 ceramic tip and stainless steel core nozzles per side. Travel speed was $6.1 \mathrm{~km} / \mathrm{h}$ in all applications. Each treatment was replicated on two plots, consisting of three bays, in separate orchard blocks. Sprays were applied to the centre row of each plot with all nozzles operating and to the adjacent rows either side, in the opposite direction of travel, with nozzles operating only on the treatment plot side. The sprayer was operated using the low fan gear with a PTO speed of $440 \mathrm{rpm}$ to deliver

Table 1 Comparison of mean canopy parameters (two replicate blocks per treatment).

\begin{tabular}{ccccccc}
\hline Replicate & Canopy & $\begin{array}{c}\text { Cane } \\
\text { density/bay }\end{array}$ & $\begin{array}{c}\text { Cane spacing } \\
(\mathrm{mm})\end{array}$ & $\begin{array}{c}\text { Canopy depth } \\
(\mathrm{mm})\end{array}$ & Leaf layers & $\begin{array}{c}\text { Canopy gaps } \\
(\%)\end{array}$ \\
\hline 1 & Dense & 24 & 245 & 519 & 7.0 & 4.3 \\
2 & Dense & 24 & 238 & 490 & 6.1 & 3.9 \\
1 & Medium & 26 & 222 & 353 & 4.3 & 18.3 \\
2 & Medium & 23 & 260 & 240 & 3.9 & 12.1 \\
1 & Light & 22 & 274 & 310 & 3.1 & $>24$ \\
2 & Light & 22 & 273 & 299 & 3.3 & 18.2 \\
\hline
\end{tabular}


approximately $32,000 \mathrm{~m}^{3} / \mathrm{h}$ of air assistance volume.

After spray treatments had dried, leaf samples were collected from up to 10 different canopy zones: upper (leaves in top of canopy shielded from sprayer), mid (leaves shielded by upper and lower canopy) and lower (exposed to sprayer) positions at the row centre, female leader zone (within one wire either side of the vine), male leader zone and randomly from the canopy tops (leaves growing at $>1 \mathrm{~m}$ above pergola wires). For the 'medium' and 'light' density canopies, where the male leader canes had been removed, a random sample was collected of leaves growing on female canes remaining in this zone. Two replicate samples of six random leaves each were collected in each zone from each replicate block, placed in resealable plastic bags and kept out of direct sunlight. They were washed with $400 \mathrm{ml}$ water containing $0.025 \%$ Du-Wett surfactant within 20 min of collection to recover dye. Prior audits (R.E. Gaskin, unpublished data) confirmed $>90 \%$ dye recovery from leaves within this time period. Spray deposits were quantified using a fluorimeter, and leaf areas were determined with a leaf area meter. Deposits were calculated as dose $\left(\mu \mathrm{g} / \mathrm{cm}^{2}\right)$ and were normalised to an equivalent spray application rate of $1 \mathrm{~kg}$ ai/ha in each treatment (to allow meaningful direct comparisons of deposits between treatments). The deposit data are presented as micrograms of dye per square centimetre of projected (onesided) leaf area. Results were statistically analysed using ANOVA to determine the significance of canopy density on spray deposits retained on leaves in different zones. Data were normally distributed and did not require transformation.
Treatment effects were considered significant at $\mathrm{P}<0.05$, and means were separated using the least significant difference (LSD) test.

\section{RESULTS AND DISCUSSION}

Average deposit data provide limited information on spray distribution within canopies, but they are useful to show gross trends. As was expected, the dense canopy received lowest deposits consistently across all canopy zones (Table 2). In the dense canopy, the centre row and female leader foliage deposits were similar, but the male leader zone with its much greater number of leaf layers (data not presented), received only two-thirds of the deposits on the more open female canopy. The medium and light density canopies retained similar deposits in the centre and (female) leader zones, and these were approximately $60 \%$ higher than for the dense canopy (Table 2). The very high deposits recorded on male leader zones in these two managed canopies were a result of male cane pruning, which fully exposed the remaining sparse foliage on female canes to sprays. Because of this, deposits from all male leader zones were excluded from analysis in the main data set (Table 3).

The dense canopy mean deposit was approximately $40 \%$ less than for medium and light canopies (Table 3). Spray deposits were distributed similarly between the centre row and leader zones in all three canopies (Table 3), which indicated that the sprayer output distribution was well matched to the canopy. This was confirmed by WSP monitoring.

Within each canopy, leaves in the lower position and closest to the sprayer always received the highest deposits (Table 3 ). In the

Table 2 Mean deposits ( $\mu \mathrm{g} / \mathrm{cm}^{2}$, normalised to a $1 \mathrm{~kg} /$ ha application of dye) on leaves in all canopy zones.

\begin{tabular}{lcccc}
\hline \multirow{2}{*}{$\begin{array}{l}\text { Canopy } \\
\text { density }\end{array}$} & $\begin{array}{c}\text { Spray volume } \\
(\text { litres/ha })\end{array}$ & Centre row & Female leader & Male leader \\
\cline { 3 - 5 } Dense & 2000 & $1.31 \mathrm{c}$ & $1.21 \mathrm{c}$ & $0.85 \mathrm{~d}$ \\
Medium & 1500 & $2.15 \mathrm{~b}$ & $1.95 \mathrm{~b}$ & $3.82 \mathrm{a}$ \\
Light & 1000 & $2.13 \mathrm{~b}$ & $2.15 \mathrm{~b}$ & $3.98 \mathrm{a}$ \\
\hline
\end{tabular}

Means sharing common postscripts are not significantly different (LSD, $\mathrm{P}=0.05$ ). 
Table 3 Mean deposits ( $\mu \mathrm{g} / \mathrm{cm}^{2}$, normalised to $1 \mathrm{~kg} / \mathrm{ha}$ application of dye) on leaves in all zones and canopy positions, excluding male leader zones.

\begin{tabular}{|c|c|c|c|c|c|c|c|c|}
\hline \multirow[b]{2}{*}{$\begin{array}{l}\text { Canopy } \\
\text { density }\end{array}$} & \multirow{2}{*}{$\begin{array}{c}\text { Spray } \\
\text { volume } \\
\text { (litres/ha) }\end{array}$} & \multicolumn{2}{|c|}{ Canopy zone $^{1}$} & \multicolumn{4}{|c|}{ Position in canopy ${ }^{1}$} & \multirow[b]{2}{*}{ Mean $^{1}$} \\
\hline & & $\begin{array}{c}\text { centre } \\
\text { row }\end{array}$ & $\begin{array}{l}\text { female } \\
\text { leader }\end{array}$ & Lower & Mid & Upper & Top & \\
\hline Dense & 2000 & $1.31 \mathrm{~b}$ & $1.21 \mathrm{~b}$ & $2.43 \mathrm{~b}$ & $0.91 \mathrm{de}$ & $1.05 \mathrm{~d}$ & $0.64 \mathrm{e}$ & $1.26 \mathrm{~B}$ \\
\hline Medium & 1500 & $2.15 \mathrm{a}$ & $1.95 \mathrm{a}$ & $3.15 \mathrm{a}$ & $1.72 \mathrm{c}$ & $1.71 \mathrm{c}$ & $1.62 \mathrm{c}$ & $2.05 \mathrm{~A}$ \\
\hline Light & 1000 & $2.13 \mathrm{a}$ & $2.15 \mathrm{a}$ & $3.36 \mathrm{a}$ & $1.81 \mathrm{c}$ & $1.82 \mathrm{c}$ & $1.58 \mathrm{c}$ & $2.14 \mathrm{~A}$ \\
\hline Mean $^{1}$ & & $1.87 a$ & $1.77 \alpha$ & $2.98 \mathrm{~A}$ & $1.48 \mathrm{BC}$ & $1.53 \mathrm{~B}$ & $1.28 \mathrm{C}$ & \\
\hline
\end{tabular}

${ }^{1}$ Means within the two "Canopy zone" columns sharing common postscripts are not significantly different (LSD, $\mathrm{P}=0.05)$. Similarly within the four "Position in canopy" columns, and for the "Mean" column and the "Mean" row.

dense canopy, the mid and upper canopy zones received similar deposits and the top foliage, most sheltered and distant from sprays, received the lowest deposits. Deposits on all foliage in the dense canopy, apart from that directly exposed to the sprayer, were considered unacceptably variable and low, with the canopy zones not directly exposed to the spray plume receiving only one-quarter to one-half the average deposit of that on the lower exposed canopy.

Deposits on the medium and light canopies were similar. In both canopies the lower leaves directly exposed to the sprayer received the highest deposits, while coverage of all other foliage was similar and considered adequate. The similarity in density between the medium and light canopies meant that the 1000 and 1500 litres/ha application volumes provided a useful confirmation of equivalent deposits when sprays are applied in volumes at or below the point of runoff with equivalent chemical application rates per hectare (concentrate spraying). In contrast, foliage in dense pergola canopies cannot be adequately covered by protectant sprays applied in the typical dilute volumes used by the kiwifruit industry, even with a good sprayer setup.

The data presented demonstrate differences in spray deposits that can be expected when equivalent amounts of chemical are applied to canopies with different total surface areas; the greater the total canopy surface area, the lower the average expected deposit per square centimetre of tissue. Airblast spray deposits will almost always be greatest in foliage directly exposed to the spray plume. A two-fold deposit variation was seen between the highest and lowest deposit samples in both the light and medium canopies in this study (Table 3). Increasing canopy density typically increases deposit variability between easily sprayed and obscured targets, and a fourfold deposit variation was seen in the dense canopy in this study.

If a chemical was applied using a label rate per 100 litre mixing concentration, the dense canopy in this experiment (2000 litres/ha) would have received twice the chemical application rate per hectare compared the light canopy (1000 litres/ ha). The data from this experiment (i.e. from Table 3, double the dense canopy deposit data and compare with the light canopy deposits) support the need to adjust chemical application rates in proportion to canopy size and/or density in order to achieve more or less equivalent deposits on different canopies. However, deposit variability caused by canopy density remains the major problem, with low and variable deposits in hard-to-reach areas of dense canopies, and a tendency to overdose tissue directly exposed to the sprayer (L.G. Hawes, HortEvaluation Ltd, unpublished data).

Control of a disease like Psa, using contact acting products, requires relatively even spray deposits and coverage. This work has confirmed that overly dense kiwifruit pergola canopies will show more deposit variability than more open canopies and that canopy management to achieve 
and maintain more open canopies is likely to be required. All foliage can be adequately covered with protectant sprays if canopies are managed to reduce their density and sprays are applied with well set-up and calibrated sprayers.

\section{ACKNOWLEDGEMENTS}

Thanks to Mike Muller for sourcing the orchard and pruning the canopies, and to D\&K Walker for the use of their orchard. R\&R Tractors Ltd provided the tractor and sprayer. Technical assistance was provided by Kevin Steele, Alison Forster, David Horgan and Justin Nairn. The study was funded by Zespri Ltd and the MPI Sustainable Farming Fund as part of the SFF Project 09/129 "Delivering orchard tools to achieve sustainable market access for kiwifruit".

\section{REFERENCES}

Manktelow D, Gaskin R, May W, Cook S 2012. Sprayers versus canopies: getting the best possible performance from kiwifruit spray applications. New Zealand Kiwifruit Journal, May/June: 24-29.

Max W, Max S 2013. Best use of agrichemicals to manage Psa. An analysis of spray diary data. New Zealand Kiwifruit Journal, January/ February: 48-51. 